\title{
HIPPOCRATES INVENTED NOTHING: POPULAR THERAPIES IN HEALING INSCRIPTIONS
}

Clarisse Prêtre ${ }^{1}$

\begin{abstract}
It has long been thought that the Hippocratic medicine in the Antiquity was opposed to the divine medicine: one was rational, the other was a mixture of superstition and religion. This article attempts to show by some examples from ancient Greek text sources that both medicines, one of the gods and one of the men, have exploited the same empirical funds from traditional care techniques. So we must now nuance the too schematic division between the two medicines.
\end{abstract}

\section{Keywords}

Asclepius ; Greek Antiquity ; Popular medecine ; Divine medecine ; Epigraphy.

\section{Resumo}

Há muito tempo tem se pensado que a medicina hipocrática na antiguidade era oposta à medicina divina: Uma era racional, a outra era uma mistura de superstição e religião. Este artigo pretende demonstrar por meio de alguns exemplos das fontes textuais da Grécia antiga, que ambas as medicinas, uma dos deuses e a outra dos homens, exploraram os mesmos fundos empíricos das técnicas tradicionais de tratamento. Pretendemos agora matizar esta divisão demasiadamente esquemática entre as duas medicinas.

\section{Palavras-Chave}

Ascelpio; antiguidade grega; medicina popular; medicina divina; epigrafia.

When one searches the Greek textual sources for an attestation of the expression "popular medicine," it is clear that no such thing exists. This notion results, in fact, from a modern construction that follows from a negative definition: popular medicine is that which is neither "professional" medicine nor medicine practiced by the gods.

\footnotetext{
${ }^{1}$ Chargé de Recherche $1^{\text {ère }}$ Catégorie, CNRS, France. email: clarisse.pretre@gmail.com 
The division often raised between the types of medicine, insofar as they exist, therefore puts the practices of a physician trained in a "school" at Cos, Alexandria, or Cnidus, for example, into opposition with practices that are not part of a formal education, such as empirical observations, and that are often mixed with religious practices and superstitious or, indeed, magical actions.

The opposition is, nevertheless, artificial, as we know that institutionalized schools did not really exist. Instead, methods and ways of thought were individually transmitted from master to student in the framework of a familial context, as is stated clearly in the Hippocratic oath: "I shall transmit the precepts, the oral lessons and all the rest of the teaching to my sons, to those of my master and to students bound by arrangement and an oath according to the medical law, but to no other person." In addition, even if professional medicine is the champion of rationalism refuting the concept of a divi- 252 -ne causality of diseases, the students of Hippocrates presented themselves as descendants of Asklepios, and in the same way, the link between religion and medicine endures.

It is therefore difficult to characterize each of these three types of medicine according to their methods, because there are so many commonalities in terms of their therapies, pathologies, and the permanent bond that forms between men and gods when disease occurs.

This holds for the Homeric period, when medicine was only in its infancy: then, surgery meant bloodletting, the extraction of arrows, or amputation, and therapies consisted of poultices or the consumption of vegetable juices intended to calm pain. The gods were frequently the inventors of medicaments used by men, ${ }^{2}$ even though certain men were already recognized for their skill in treating and healing. In book IX of the Iliad, the physician Machaon is wounded and is granted special attention, "because a single physician is worth many men, for extracting arrows by incision and for applying calming remedies on wounds." 3

At the start of the Classical era, medicine was formalized and divided into dietetics, pharmaceutics, and surgery, but the intervention of the gods remained unquestioned. This is proven in Aeschylus' Prometheus Bound, in which the Titan recalls his primordial role in the creation of medicine. "For a lack of

\footnotetext{
2 Plant names were also often inspired by the gods. Cf. Fabre A-J Mythologie et plantes médicinales de l'Antiquité Hist Sci Med 2003;37-1:65-87.

${ }^{3}$ Iliad XI, 513-515.
} 
medicaments, all men would be dying; but it is I who taught them how to compose salutary remedies." 4

One might think that the rise of Hippocratic medicine would signal the end of these popular therapeutic practices inspired by the gods. Certain epigraphic sources from the 4th century attest, however, to the strength of empirical medicine; the first iamata, texts written principally at the sanctuary of Asklepios at Epidauros, ${ }^{5}$ are contemporary to Hippocrates, and therefore to the beginning of the confrontation between a belief in divine causality and medical rationalism. Even though the iamata were devised for the glory of the healing god, they also offered a mix of lexical imprecision -- to be expected, since priests and not physicians officiated at the sanctuary -- and rational medical procedures derived from traditional therapeutics. The medicine described in the iamata is a continuation of popular medicine, combining mineral and organic principles that had been known for quite a long time.

This is not the place to enumerate all the modes of "popular" therapy practiced in the sanctuaries of the healing gods. We will, rather, focus on some examples that highlight a sort of typological recurrence of remedies or gestures that originated in traditional techniques, but that later inspired professional medicine.

In this way, topical preparations were often composed of ingredients that individually hardly possessed any therapeutic value, but that became active once they were mixed.

The poultice prescribed by Asklepios to P. Granius Rufus is a testimony to this efficiency:

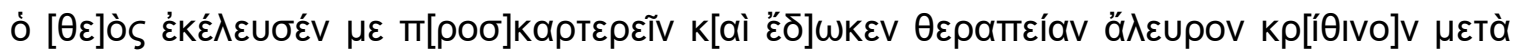

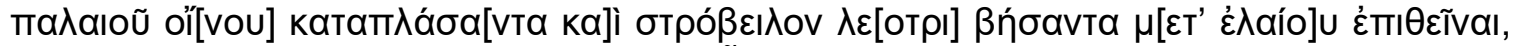

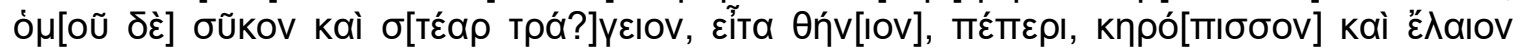

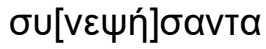

After having made a poultice of wheat flour and old wine, and after having reduced into a fine powder pine nuts with oil, apply them, at the same time as some fig and some goat fat, then milk, pepper, and after having mixed, some ointment of wax and pitch with some oil. ${ }^{6}$

The use of these elements (wheat flour, old wine, pine nut, oil, fig, goat fat, milk, pepper, wax, pitch) can be observed in other traditional remedies, but it is

${ }^{4}$ Prometheus Bound, 478-483.

${ }^{5}$ But also at Lebena on Crete and, later, at Rome

${ }^{6}$ Inscriptiones Creticae I XVII 18 
interesting to note that their real medical guarantee came a century and a half later with Celsus, who used these ingredients in his recipes for softening poultices and extractives in the case of scrofula. ${ }^{7}$

Similarly, a woman thanked Asklepios for having healed an ulceration on her finger:

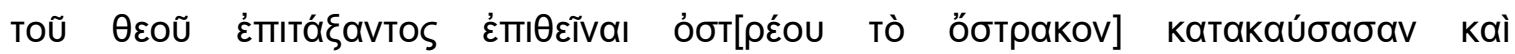

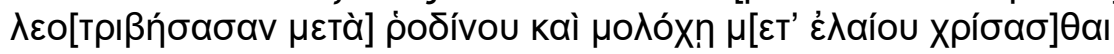

The god prescribed that she should apply an oyster shell after having completely burned and reduced it into a fine powder with some rose, and to rub it with mallow oil. ${ }^{8}$

The use of some of these ingredients for ulcerations was rare in "professional" medicine, appearing only in some Hippocratic remedies containing oyster ash. This was often incorporated into foods in certain recommended diets, but rarely had a real therapeutic value. It is necessary to wait for later authors to see a synthesis of the qualities of this powder. Galen used it in this way for a case of inflammation of the parotid gland: "Oyster-shell ash has the same quality when it is applied with honey," ${ }^{9}$ but it never was used in the composition of ointments or balms for external usage.

The ulceration on the woman's finger did not benefit from any surgical intervention, nor from any incision, but from an application of mallow oil: this, too, is a trace of a popular therapy, in which the applications of plants were privileged more than invasive operations. Mallow was, in fact, used in the ancient pharmacopoeia for its value in treating various stings and Pliny the Elder, well after the Lebena inscriptions, described its properties:

This plant has efficacious properties against all stings, especially those of scorpions, wasps and similar insects, and against the bite of the shrew. Moreover, those who have previously rubbed themselves with any of the mallows pounded in oil, or have some on them, will not be bitten. ${ }^{10}$

Once more, the mixture of ingredients for the most varied treatments existed before professional medicine.

Outside of topical applications, traditionally-used decoctions and potions included elements with qualities that were sometimes not accepted by the

\footnotetext{
${ }^{7}$ Celsus De medicina Nis5 16-17

8 Inscriptiones Creticae I XVII 19

${ }^{9}$ Galen De compositione medicamentorum secundum locos liber III, cap. II, K12, 669 1. 5.

10 Pliny the Elder Historia Naturalis 20, 84
} 
physicians. It is also symptomatic that the term $\chi 0 \lambda$ òs, which from Plato to Theophrastus had always designated fruit juice and sap, took on the new sense of "decoction" for the first time in the iamata, an evident vector of popular and empirical medicine. In the medical literature, Dioscorides used its original meaning when he spoke of the "juice of leaves," $\chi 0 \lambda$ òs $\tau \tilde{\omega} \mathrm{v} \varphi \dot{\nu} \lambda \lambda \omega \mathrm{v}, 11$ but then began to use the term for all sorts of mixtures, often when honey was included in the composition. ${ }^{12}$ According to Galen, $\chi 0 \lambda$ ós was most frequently the result of a

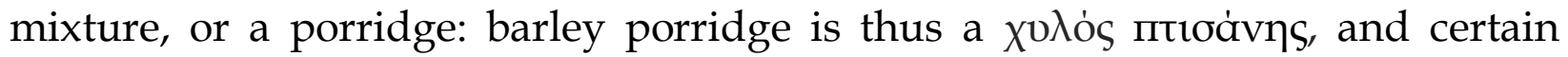
mixtures were diluted with water. ${ }^{13}$

The iamata include numerous examples of complex potions of which we find no trace in the Hippocratic treatises.

This is the case for P. Granius Rufus, attacked by a severe purulent cough, who benefitted from a concoction composed of numerous ingredients: their therapeutic properties were proven when used separately, but the fabrication of a remedy made by combining them all is attested for the first time in the iamata and testifies to the ingenuity of popular medicine compared with therapies in Hippocratic medicine.

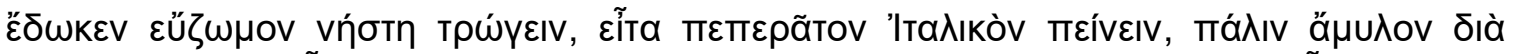

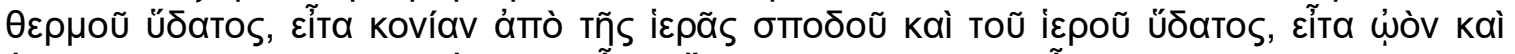

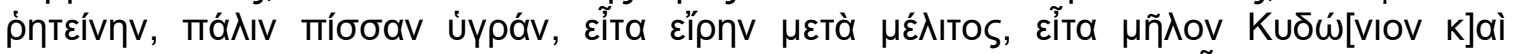

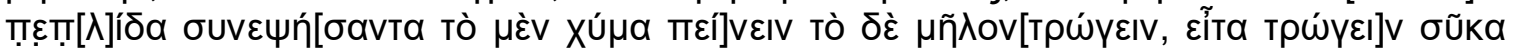

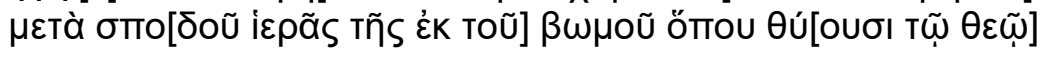

He had me eat arugula on an empty stomach, then drink peppered Italian wine, then starch in hot water, powder of sacred ash in holy water, an egg with pine resin, and also raw pitch, then iris in honey; then he had me drink quince juice mixed with spurge, eat an apple, then a fig with sacred ash coming from the altar on which one sacrifices to the god. ${ }^{14}$

The therapeutic value of the different active principles used in the course of the treatment of this patient lay very much in their association. If we consider the ingredients in detail, arugula used alone possessed properties that are essentially diuretic and aphrodisiac; starch was used for the cure of digestive and general intestinal troubles; quince was above all known for its property of comforting the intestines; spurge was a renowned purgative, and the fig was even seen to be

\footnotetext{
11 Dioscorides De materia medica I 80, 1, 1.1 (Wellmann)

12 Dioscorides De materia medica I 126, 1, 1. 3;II, 151, 1, 7 (Wellmann)

${ }^{13}$ Galen De sanitate tuenda liber IV, cap. IV, K6, p. 260, 1. 15. SESp.5. Galien, De alimentarum facultatibus, liber I, cap. VI, K6, p. 497, 1. 4

14 Inscriptiones Creticae I XVII, 17
} 
dangerous because it could cause a disturbance of the humors. The presence of the powder of sacred ash accompanied by holy water underlines the divine character of the therapy and has no active therapeutic principle. It is reminiscent of a later iama of the second century of our era, in which a pleuritic was cured when the god made an oracle: "Let him take some of the ash on the triangular altar, let him mix it with wine and apply it to his side." 15 The efficacy of the ash in the hot poultice could be accepted in the second case but in the first, its role in the composition of the remedy is strictly symbolic and testifies to the force of the popular beliefs that infiltrated therapeutic practices with rational appearances.

P. Granius Rufus was therefore healed of his pulmonary affliction by the interactions of a mixture of ingredients that had no anti-cough properties when taken individually. Once again, empirical medicine proved itself to the point that Celsus ${ }^{16}$ was inspired by it a century later in the section that he dedicated to the cough, by synthesizing some of these medications. Even the figs are cooked on the coals, not unlike those prescribed for Granius Rufus on the sacred coals of the Asklepian sanctuary. Also present are starch, wine, honey, and hot water. This makes for a good example of the reappropriation of popular therapies by professional medicine.

Besides the remedies for external or internal usage about whose curative properties there is no doubt, certain modes of therapies seem to have come from a popular medical tradition that was not taken up later as part of rational practices. The intervention of exterior elements unrelated to the pharmacopoeia or surgery testify not only to the force of popular medicine, but also to a certain form of conservatism that Hippocratic medicine continued to fight and denounce.

The presence in the iamata of animals that helped to heal patients is without doubt the therapeutic process most firmly anchored in the older tradition of therapy. The relationship between man and animal in antiquity evolved over the course of the centuries. While the Homeric epics established an almost egalitarian relationship between the two, opposing their state of mortality with that of the immortal gods, the advent of logos in the Archaic period placed animals in an inferior position defined perfectly by Isocrates. ${ }^{17}$ In the iamata, the active involvement of certain animals breaks with this rational schema by

\footnotetext{
${ }^{15}$ Inscriptiones Graecae XIV 966

${ }^{16}$ Celsus De medicina Nis4:4, 4

${ }^{17}$ Isocrates Nicocles of the Cyprians:3, 5-6.
} 
including them directly in the therapeutic process that resulted from popular beliefs.

Thus, the dog is one of the most recurrent animals in healing acts even though the Greeks often considered it an impure animal. In the Epidauros inscriptions, two children were healed of an ulcer and of blindness by the dogs of the sanctuary:

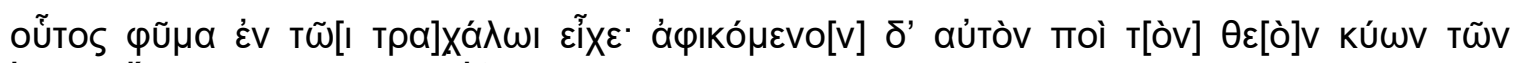

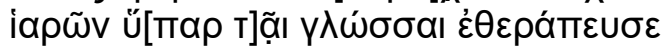

One had an abscess in his neck. When he came to the god, a sanctuary dog bathed him while awake with his tongue and he was returned to health. ${ }^{18}$

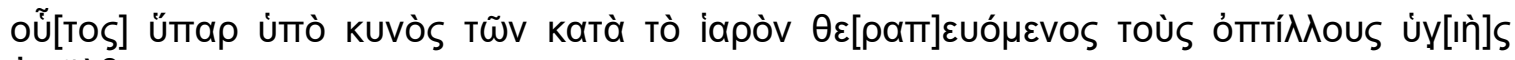
ámก̃ $\lambda \theta \varepsilon$

One returned to good health because his eyes were washed by one of the dogs of the sanctuary while he was awake. ${ }^{19}$

Pausanias reports that one of the dogs had been represented at the feet of the statue of Asklepios at Epidauros, by the sculptor Thrasymedes of Paros. ${ }^{20} \mathrm{He}$ also relates the legend according to which the infant Asklepios, abandoned to the care of a goat by his mother Koronis, had been guarded by a sheepdog. ${ }^{21}$ This explains the consideration accorded to dogs in the sanctuaries of the god, in the same way as serpents, even though Hippocratic medicine considered them impure animals. However, if the use of dog saliva to heal wounds could seem devoid of all rational validity, in practice it demonstrates once more the great empirical knowledge shown by the healing personnel of the temples: retrospective diagnostics prove the efficiency of this therapy of contact, canine saliva being characterized by a concentration of leukocytes, which are associated with active cleansing ingredients present constitutionally, much more elevated than in human saliva. ${ }^{22}$

This technique of treatment with dog saliva clearly developed from a popular tradition; it was later restored in the animal writings of Aelian. Only then did the dog reclaim the function that had been his with Asklepios: the animal knew how

\footnotetext{
${ }_{18}$ Inscriptiones Graecae IV2 1, 122, XXVI

${ }^{19}$ Inscriptiones Graecae IV 1,121, XX.

20 Pausanias Periegesis:II, 27, 2:sẸ:

${ }^{21}$ Pausanias Periegesis:II, 26, 4.

${ }^{22}$ Duncan AW, Maggi RG, Breitschwerdt EB Bartonella DNA in dog saliva Emerg Infect Dis 2007;13:1948-1950
} 
to choose healing herbs, his saliva had antiseptic properties, and finally, he sensed illnesses and therefore prevented them from developing on to incurable stages. $^{23}$

The other animal associated with healing is the serpent, which combines religious Asklepian symbolism and belief together with its therapeutic efficacy: it is sometimes difficult, in the accounts, to distinguish between real medical action and religious superstition linked to the popular imagery of the serpent and of Asklepios. The foundation myths of the sanctuaries indeed reserve a central place for the serpent: thus the city of Halieis explains the construction of its temenos with the arrival of a serpent escorting an invalid who had not been healed at Epidauros. ${ }^{24}$ The story is comparable to the legend of the foundation of the Asclepieion on the Tiber island at Rome when, struck by pestilence in 293 B.C., it had sent an embassy to find the god at Epidauros in order to found a temple: his divine epiphany was made in the form of a snake that chose the site of his future cult at Rome. ${ }^{25}$

However, Aristophanes, a contemporary of certain Epidaurian iamata, already did not hesitate in his Ploutos to mock popular belief in the healing power of the serpent. The protagonist, accompanying his master during his incubation at the sanctuary, is more concerned with the food left in offering to the god than with the healing; to acquire a plate of gruel, he counterfeits the intervention of a serpent: "The old woman, hearing the noise that I was making, reaches out her hand: I hiss, I seize it, and I bite it, as if I am a sacred serpent. She pulls her hand back immediately..." 26 Further, it is Ploutos himself who is healed of his blindness by two serpents. "These, having quietly slipped under the cloak, licked his eyelids, as it seemed to me... Ploutos rose seeing clearly."

A relief from Epidauros bears the same type of scene with an old man with swollen feet carried on a stretcher under a tree; his slaves let down the serpent that will heal him. ${ }^{27}$

\footnotetext{
${ }^{23}$ Aelian History of Animals V, 46 and VI, 16

${ }^{24}$ IG IV $^{2}$ 1, 122, XXXIII

${ }^{25}$ Ovid Metamorphoses:XV, 622-744

${ }^{26}$ Aristophanes Ploutos:689-690 and 735-736

${ }^{27}$ Hamperl H Versuch der Deutung einer Wunderheilung von Epidauros, Archäologischer Anzeiger 1963:89-93. Bas-relief 233a at the Ny Carlsberg Glyptotek in Copenhagen.spep:
} 
The healing intervention of serpents is, therefore, of two sorts in the Epidaurian texts: by bite and application of saliva on one side, and by simple contact on the other, enabling a divine power more than providing a veritable treatment.

As with the dog, one recognizes in the saliva of serpents antiseptic powers that were not recognized by later ancient medical professionals, despite the scientific validity of this belief. ${ }^{28}$ Thus, a man attacked by an ulceration benefitted from this type of treatment:

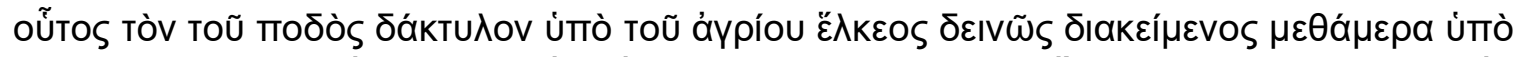

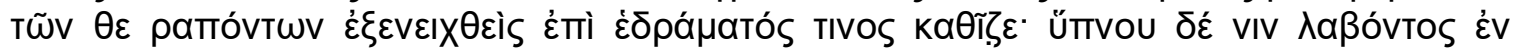

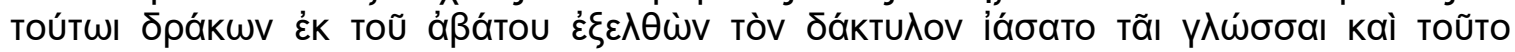

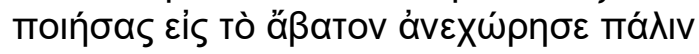

This one's toe was in a bad state because of a nasty swelling. That day, he had been carried by servants and remained seated on a chair. As he was taken by sleep, a serpent coming out of the abaton cured his foot with his tongue, and after this, returned again in to the abaton. ${ }^{29}$

In another, a woman's abscess was incised by the fangs of a viper:

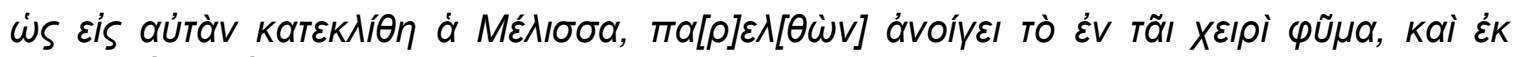

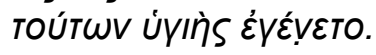

When Melissa lay down, the viper arrived by her side and opened the abscess on her hand, and following this, Melissa recovered her health..$^{30}$

This case of incision by bite is one of the rare attestations of a surgical practise transposed into a popular procedure, with the serpent substituting for the hand of the surgeon in the opening and emptying of the wound.

The other cases of the intervention of a serpent in the iamata possibly relate more to a sexual fantasy than to a veritable therapeutic activity. In the two stories, women come to Epidauros to address their sterility:

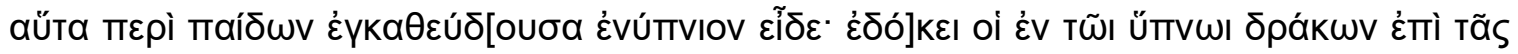

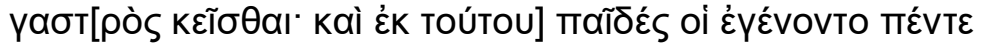

When she came to sleep here in order to have children, she had a vision in a dream. She believed in her sleep that a serpent coiled up on her belly. After this, she had five children.

\footnotetext{
28 Angeletti LR, Agrimi U, Curia C, French D, Mariani-Costantini R Healing rituals and sacred serpents. Lancet 1992;340:223-225

${ }^{29}$ Inscriptiones Graecae IV 1,121, XVIII

${ }^{30}$ Inscriptiones Graecae IV2 1, 123, XLV
} 


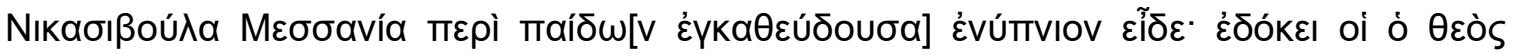

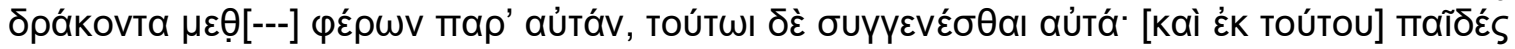

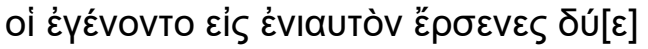

Nikasiboula of Messene, who came to sleep here on the subject of children, had a vision in a dream: she believed that the god had carried a serpent close to her and that she became one with it. Following this, she had two boys within the year. ${ }^{31}$

In addition to the phallic symbolism of the story, taken up later by Artemidoros, ${ }^{32}$ we should add the prestige of hierogamy, even in animal form. The belief remained popular here, but had derived from the shift of therapeutic actions to religious ones.

These examples, among others, also demonstrate that the presence of attendants helping in the therapeutic interventions in the healing sanctuaries is assured. The iamata are the inverse reflection of rational medical theories: the force of popular belief in divine action was necessarily infiltrated by Hippocratic methods, and notably by surgical techniques, but also by an ancestral knowledge of the usage of plants for the most varied remedies.

The therapies described in these inscriptions can in no way be assimilated to those of charlatans, and magico-religious practices like incantations are absent from the above cases.

The motivations that brought an invalid to turn to these divine therapies rather than professional medicine remain to be understood. Often, it is a return to practices known for a long time, following a venture into Hippocratic medicine. A visit to the sanctuary of Asklepios often constituted a last hope for healing, because of the reassuring alliance of empirical medicine and religion. Thus Aristagora of Trezene, after numerous setbacks with physicians, turned to Asklepios who healed her of a tapeworm. ${ }^{33}$ Hippocratic medicine was still in its infancy, and the epigraphic texts relate the successes of the god through methods and therapeutics close to those of popular medicine.

Far from disappearing in the wake of rational medical advances, popular medicine found in divine therapy a means of assuring its continuity. The iamata constitute a written form indispensable to the translation of ancestral knowledge.

\footnotetext{
${ }^{31}$ Inscriptiones Graecae IV2 1, 122, XXXIX et XLII

32 Oneirocritica 2,13 and 4,66

${ }^{33}$ Inscriptiones Graecae IV 1, 122, XXIII
} 